\title{
Uniwersytety ludowe w II Rzeczypospolitej (zarys problemu)
}

\section{Folk Universities \\ in the Second Polish Republic \\ (An Outline of the Issue)}

\begin{abstract}
ABSTRAKT
Zainteresowanie polskich środowisk oświatowych ideq uniwersytetu ludowego - placówki edukacji pozaszkolneji przeznaczonej dla młodzieży wywodzacej się ze wsi i kształcacej na potrzeby tego środowiska przodowników pracy oświatowej i kulturalnej - wzmogło się wraz z odzyskaniem przez Polskę niepodległości. W Polsce międzywojennej ukształtował się wręcz żywy ruch uniwersytetów ludowych (obejmujący w sumie 27 placówek tego rodzaju). Szczególnq rolę w jego rozwoju odegrały takie postacie, jak ks. Antoni Ludwiczak, Ignacy Solarz, Jadwiga Dziubińska.

Otwarcie pierwszego polskiego uniwersytetu ludowego w Polsce międzywojennej nastapiło z inicjatywy Towarzystwa Czytelni Ludowych, w Dalkach pod Gnieznem, 5 października 1921 roku. Jego dyrektorem został, stojący na czele Towarzystwa, wspominany ks. Antoni Ludwiczak. W placówce tej-podobnie jak w innych uniwersytetach założonych później przez TCL (w Zagórzu na Kaszubach - w 1926 roku i Odolanowie na południu Wielkopolski z przeznaczeniem dla
\end{abstract}

SLOWA KLUCZOWE uniwersytety ludowe, oświata pozaszkolna, Polska międzywojenna, ks. Antoni Ludwiczak, Ignacy Solarz

\section{KEYWORDS}

folk universities, education outside of school, Interwar Poland, Father Antoni Ludwiczak, Ignacy Solarz

SPI Vol. 19, 2016/2

ISSN 2450-5358 e-ISSN 2450-5366 DOI: 10.12775/SPI.2016.2.009 Artykuły i rozprawy 
młodzieży ze Ślqska - w 1927 roku) - eksponowano wychowanie Polaka-katolika. Realizowany w niej program charakteryzował się wyraźna dominacją treści historyczno-literackich.

Profil kształcenia w uniwersytecie w Dalkach nie satysfakcjonował ¡ednak części młodzieży wiejskiej, radykalizujq̨cej się pod względem społecznym i ideowym oraz zwiqzanych z niq działaczy ludowych starszego pokolenia. W tych środowiskach uznawano, że jest on za mało "wiejski”. W konsekwencji powołano do życia nowy (wiejski) uniwersytet ludowy - w 1924 roku w Szycach - realizujacy koncepcje tzw. „chłopskiej szkoły", której głównym twórcq był Ignacy Solarz. Profil edukacji w tej placówce (kontynuowany później przede wszystkim w uniwersytecie ludowym w Gaci Przeworskiej) wynikał przede wszystkim z powiqzań z ruchem młodochłopskim i z tendencji do wychowania młodzieży wiejskiej w ścisłej łączności z warstwq chłopskq oraz jej dqżeniami do przebudowy politycznej i społeczno-kulturalnej wsi i państwa.

Na podstawach ideowych zbliżonych do głównych założeń koncepcji Solarza opierała się także działalność uniwersytetu ludowego w Sokołówku, założonego w 1927 roku i prowadzonego (dla dziewczq̨ wiejskich) przez Jadwigę Dziubińskq. Realizował on jednak model uniwersytetu będqcego z jednej strony instytucia pogłębiajacq przygotowanie zawodowe (szczególnie w zakresie praktyki agronomicznei), z drugiej - stanowiq̨cq ogólnokształcqcą nadbudowę wykształcenia ogólnorolniczego na poziomie niższym (do uniwersytetu przyjmowano właściwie absolwentki ludowych szkół rolniczych).

\section{ABSTRACT}

The interest on the part of educational communities of the idea of folk universities - an extracurricular educational venue aimed at the young from rural areas and providing leaders in eduational and cultural work with education so as to fulfil the needs of their region - increased along with Poland regaining independence. In fact, in the interwar Poland, an active movement of folk universities was created (consisting of 27 institutions of the kind). Father Antoni Ludwiczak, Ignacy Solarz, Jadwiga Dziubińska were the people who played an exceptional role in its development.

The first Polish folk university in the inerwar Poland was opened with the initiative of the People's Libraries Societies (Polish: Towarzystwo Czytelni Ludowych) in Dalki near Gniezno, on $5^{\text {th }}$ October in 1921. The above-mentioned Father Antoni Ludwiczak, who was in charge of the society, became the director of the university. In the institution, similar- 
ly to other universities established later by the society (in Zagórze in Kaszuby in 1926, in Odolanów in the south of Wielkopolska aimed at the young from Silesia - in 1927) the education of Catholic Poles was emphasised. The curriculum realised in the university was characterised by its distinctly dominant historic and literary content.

The educational profile in the university in Dalki did not satisfy some of the young people from rural areas, who were becoming more radical in social and ideal terms as well as the peasant activists from the older generation associated with them. In these circles, it was claimed that it was not "rural" enough. As a consequence, a new (rural) folk university was established - in 1924 in Szyce - fulfilling the idea of the co-called "folk school", the main founder of which was Ignacy Solarz. The educational profile of the institution (later continued, most of all, in the folk university in Gać Przeworska) resulted from its associations with the young peasant movement and with the tendencies to educate the young from rural areas in close cooperation with peasant social class and their attempts to reconstruct the Polish countryside politically, socially and culturally, as well as the country itself.

The folk university in Sokołówek was established (for female students) in 1927 and was directed by Jadwiga Dziubińska based on ideological foundations similar to the main assumptions of the concept of I. Solarz. However, it realised the model of university as an institution which, on the one hand, improved vocational preparation (especially in terms of agronomic practice) and, on the other hand - was a general expansion of general agricultural education on a lower level (the university enrolled graduates from folk agricultural schools).

\section{Uwagi wstępne}

W Polsce międzywojennej w wielu środowiskach oświatowych, w tym także w tych zbliżonych do wsi i popierających jej edukacyjne aspiracje, podzielano opinię, że szkolnictwo stanowi tylko jedno z ogniw szeroko pojętej oświaty. Wspierająca oświatowe dążenia ówczesnej wsi Helena Radlińska - nawiązując do swojego stanowiska na temat oświaty pozaszkolnej, zajmowanego jeszcze w okresie niewoli narodowej - pisała u progu niepodległości w 1919 roku, że

organizacja szkolnictwa nie obejmuje jeszcze wszystkiego, co trzeba robić. Nie można ludzi rozbudzonych przez szkołę, zostawić potem na pa- 
stwę śpiączki umysłowej, nie można dziś, gdy wszyscy ludzie dorosli budują dla następnych pokoleń nowe życie, poprzestać na uczeniu dzieci ${ }^{1}$.

Wyrażając nadzieję, że odrodzona niepodległa Polska oparta będzie na nowych demokratycznych podstawach społecznych i politycznych, stwierdzała dalej, iż państwo

musi udostępnić każdemu obywatelowi: książki, obrazy, wiedzę i muzykę. Trzeba całą Polskę pokryć siecią bibliotek powszechnych, zakładać piękne domy ludowe, urządzać wystawy, odczyty i koncerty. Trzeba założyć dla młodzieży dorosłej szereg uniwersytetów ludowych, w których zapoznawać się będą ze słonecznym światem kultury. Trzeba, by obok instruktorów rolnictwa, ogrodnictwa itp., szli przez Polskę organizatorzy czytelni, chórów, teatrów, związków samokształcenia ${ }^{2}$.

W okresie II Rzeczypospolitej, oprócz wielu różnych instytucjonalnych form edukacji pozaszkolnej, wskazywano także na instytucję uniwersytetu ludowego, przeznaczoną dla młodzieży wywodzącej się ze wsi i kształcącej na potrzeby tego środowiska przodowników pracy oświatowej i kulturalnej. Rola tej instytucji edukacyjnej została potwierdzona także oficjalnym zarządzeniem polskich władz oświatowych pod koniec okresu międzywojennego (w lutym 1939 roku), uznającym „uniwersytet ludowy za stałą placówkę oświaty dorosłych o charakterze powszechnym"3.

Zainteresowanie polskich środowisk oświatowych ideą uniwersytetu ludowego, która zrodziła się w Danii ${ }^{4}$, wzmogło się wraz z od-

1 H. Radlińska przedstawiła to stanowisko m.in. w referacie zaprezentowanym podczas obrad II Kongresu Pedagogicznego we Lwowie 1909 roku, twierdząc wprawdzie, że najważniejszą częścią wychowania jest szkolnictwo, zarazem podkreślała, że nie jest ono jedyną jego formą organizacyjną. Konstatowała, że „obok niego, nieraz silniej działają inne wpływy wychowawcze - przykład otoczenia i atmosfera ogólna; dopełniają je, nieraz zastępują, instytucje oświaty pozaszkolnej, biblioteki, muzea, uniwersytety ludowe". Cyt. za: W. Jamrożek, Kongresy i zjazdy pedagogiczne w rozwoju polskiej myśli i praktyki edukacyjnej (do 1939 roku), Poznań 2015, s. 36.

2 H. Radlińska, Oświata i kultura wsi polskiej. Wybórpism, oprac. H. Brodowska, L. Wojtczak, Warszawa 1979, s. 170.

3 J. Sutyła, Miejsce ksztatcenia dorostych w systemie oświatowym II Rzeczypospolitej, Wrocław 1982, s. 140.

4 Zob. m.in. A. Bron-Wojciechowska, Grundtvig, Warszawa 1986, s. 39, 75 i nast.; L. Turos, Uniwersytet ludowy Ignacego Solarza i jego wychowankowie, Warszawa 1970, s. 22 i nast.; M. Rosalska, Katolickie uniwersytety ludowe wobec przemian wspótczesnej wsi polskiej, Poznań 2004, s. 9 i nast. 
zyskaniem przez Polskę niepodległości, to jednak znana ona była na ziemiach polskich już wcześniej. Przyjmuje sie również, że pierwsze polskie instytucje oświatowe nawiązujące do doświadczeń i koncepcji Mikołaja F.S. Grundtviga i Kristiana Kolda powstały na ziemiach polskich jeszcze w okresie niewoli narodowej. Chodzi tutaj przede wszystkim o „fermę ogrodniczą”, prowadzącą kursy dla dorosłych włościan uczących się ogrodnictwa i pszczelarstwa, powstałą w Pszczelinie w 1900 roku i kierowaną przez Jadwigę Dziubińską. W programie kształcenia realizowanym w tej placówce znajdowały się elementy edukacji ogólnej, służące uświadomieniu obywatelskiemu wychowanków i „przyzwyczajaniu ich do życia kulturalnego" ${ }^{5}$. Na wzór tej „szkoły” Jadwiga Dziubińska założyła w 1905 roku w Kruszynku żeńską szkołę rolniczo-gospodarską dla córek drobnych rolników. Cech charakterystycznych dla duńskiej koncepcji uniwersytetu ludowego dopatrywano się także w działalności kolejnych internatowych „szkół rolniczych” w Gołotczyźnie, Sokołówku i Krasieninie. Szkoły te wzorowały się na placówkach w Pszczelinie i Kruszynku6.

\section{Ruch uniwersytetów ludowych w Polsce międzywojennej}

W II Rzeczypospolitej, jak konstatowała Jadwiga Sutyła - jedna $\mathrm{z}$ badaczek zagadnień kształcenia dorosłych w tamtym czasie - można wyróżnic dwa podstawowe okresy w rozwoju ilościowym uniwersytetów ludowych:

- pierwsze piętnastolecie, charakteryzujące się powolnym powstawaniem tych placówek (utworzono wówczas tylko osiem uniwersytetów: w Dalkach, Szycach, Zagórzu, Odolanowie, Sokołówku, Nałęczowie, Gaci, Michałówce; przy czym tylko pięć z nich funkcjonowało dłużej: w Dalkach, Szycach, Sokołówku, Gaci, MichaHówce);

- ostatnie pięć lat poprzedzających wybuch wojny (1934-1939), na które przypada wzrost liczby uniwersytetów ludowych (w lutym

5 S. Michalski, Wiedza rolnicza w walce o postęp na wsi. Rzecz o Jadwidze Dziubińskiej, Warszawa - Poznań 1981, s. 18 i in.

6 Zob. K. Wojciechowski, Początki i rozwój uniwersytetów ludowych w Polsce do 1945 roku, w: Uniwersytety ludowe w Polsce i za granica, red. A. BronWojciechowska, Warszawa 1977, s. 17-28; T. Pilch, Uniwersytet ludowy, w: Encyklopedia pedagogiczna XXI wieku, t. 6, Warszawa 2007, s. 1021-1022. 
1939 roku funkcjonowały 22 placówki); oprócz już działających powstały nowe: w Tywonii (póżniej po przeniesieniu w Grzędzie), Różynie, Głuchowie, Prudziszcze, Ujeznej, Suchodole, Nietążkowie, Wąchocku, Żernej, Nierodzimiu, Ohladowie, Bryskach, Proboszczowicach, Krzyżanowicach, Bolszewie, Kopcu, Małyńsku .

Do podmiotów prowadzących uniwersytety ludowe w Polsce międzywojennej należały: Towarzystwo Czytelni Ludowych, Związek Polskiego Nauczycielstwa Szkół Powszechnych, Spółdzielnia Rolnicza dla Prowadzenia Uniwersytetów Wiejskich, Seminarium dla Nauczycielek Szkół Rolniczych (w Sokołówku), Zarząd Okregu Lubelskiego Związku Nauczycielstwa Polskiego, Towarzystwo „Przodownik Wiejski” (od 1938 roku - Towarzystwo Wiejskich Uniwersytetów Ludowych) i związane z nim Towarzystwo Uniwersytetów Wiejskich Województwa Białostockiego oraz Towarzystwo Uniwersytetów Wiejskich Województwa Łódzkiego, Liceum Krzemienieckie, Związek Osadników (Prudziszcze pod Wilnem), agendy Akcji Katolickiej (Dicezjalne Instytuty Akcji Katolickiej w Przemyślu, Płocku, Tarnowie), Związek Młodzieży Ludowej, Wielkopolski Związek Młodzieży Wiejskiej, Katolickie Stowarzyszenie Młodzieży Diecezji Sandomierskiej, Towarzystwo Szkoły Ludowej, Towarzystwo Salezjańskie, Funadacja im. Klonowskiego9. Spośród wymienionych podmiotów najwięcej placówek (pięć) prowadziło w II Rzeczypospolitej Towarzystwo „Przodownik Wiejski” (Towarzystwo Wiejskich Uniwersytetów Ludowych): od 1932 roku placówkę w Szycach, następnie uniwersytet powołany we wsi

7 W Polsce w okresie międzywojennym działało w sumie 27 uniwersytetów ludowych, jednak nie wszystkie placówki dotrwały do 1939 roku, niektóre z nich przerywały działalność, która była później wznawiana (np. w Szycach, w Sokołówku).

8 J.Sutyła,Miejsce ksztatcenia dorostych wsystemie oświatowym II Rzeczypospolitej, dz. cyt., s. 140. W literaturze przedmiotu funkcjonuje jeszcze inna periodyzacja dotycząca rozwoju ruchu polskich uniwersytetów ludowych w dwudziestoleciu międzywojennym. Według niej wyodrębnia się okres do 1931 roku i lata 1932-1939, a wewnętrzną cezurę tego podziału stanowi powołanie do życia w 1932 roku drugiej uniwersyteckiej placówki Ignacego Solarza w Gaci Przeworskiej. Zob. T. Maliszewski, Uniwersytety ludowe na ziemiach polskich w XX stuleciu, w: Uniwersytet ludowy - szkota dla życia, red. M. Byczkowski, T. Maliszewski, E. Przybylska, Wieżyca 2003, s. 87.

9 Por. T. Pilch, Uniwersytet ludowy, dz. cyt.; F. Popławski, Polski uniwersytet ludowy, Warszawa 1985; J. Sutyła, Miejsce kształcenia dorostych w systemie oświatowym II Rzeczypospolitej, dz. cyt. 
Grzęda pod Lwowem (placówkę przeniesioną z Tywonii), uniwersytet w Głuchowie, w Suchodole i w Żernej (TUW Województwa Białostockiego). Niewiele mniej (w sumie cztery, w różnym czasie) prowadziło Towarzystwo Czytelni Ludowych. Spośród placówek związanych z TCL do końca okresu miedzywojennego przetrwały dwie: w Dalkach (w Wielkopolsce) i w Bolszewie (na Pomorzu) ${ }^{10}$.

Ze względu na orientację ideową oraz realizowane koncepcje programowe i powiązania organizacyjne, wśród uniwersytetów ludowych działających w Polsce międzywojennej można wyodrębnić:

- placówki o orientacji katolickiej (Dalki, Odolanów, Zagórze, Ujezna, Proboszczowice, Wąchock, Bolszewo, Krzyżanowice, Kopiec);

- placówki (wiejskie uniwersytety ludowe) związane z ruchem młodowiejskim i poszczególnymi jego odłamami (z radykalnym pod względem społecznym i politycznym ruchem młodochłopskim oraz politycznym ruchem ludowym: Szyce - do 1931 roku, Sokołówek, Nałęczów, Gać, Nietążków; związane z częścią ruchu młodowiejskiego o orientacji propaństwowej, prowadzone przede wszystkim przez Towarzystwo „Przodownik Wiejski” - Towarzystwo Wiejskich Uniwersytetów Ludowych: Szyce - od 1932 roku, Grzęda, Głuchów, Suchodół);

- placówki o charakterze narodowym i regionalnym, powiązane $\mathrm{z}$ różnymi innymi podmiotami (Michałówka, Prudziszcze, Różyn, Małyńsk, Nierodzim).

\section{Uniwersytet ludowy ks. Antoniego Ludwiczaka}

Otwarcie pierwszego polskiego uniwersytetu ludowego w II Rzeczypospolitej - w pełnym tego słowa znaczeniu - nastąpiło z inicjatywy Towarzystwa Czytelni Ludowych ${ }^{11}$ w Dalkach pod Gnieznem w dniu 5 października 1921 roku. Jego dyrektorem został, stojący na czele Towarzystwa, ks. Antoni Ludwiczak (interesujący się ideą uniwersytetów

10 Zob. K. Kabziński, Powstanie $i$ dziatalność uniwersytetów ludowych Towarzystwa Czytelni Ludowych w okresie międzywojennym, w: Instytucjonalne formy edukacji dorostych w Drugiej Rzeczypospolitej, red. E. Sapia-Drewniak, A. Stopińska-Pająk, Warszawa 2001, s. 109-120.

11 Towarzystwo Czytelni Ludowych powstało w zaborze austriackim jeszcze w okresie niewoli narodowej, w 1880 roku. Zob. szerzej: K. Kabziński, Funkcja spoteczno-wychowawcza i oświatowa Towarzystwa Czytelni Ludowych (1880-1939), Wrocław 1985. 
ludowych jeszcze w okresie przed odzyskaniem niepodległości). Funkcję dyrektora uniwersytetu w Dalkach pełnił do 1938 roku.

Uniwersytet ludowy w Dalkach, kształcący chłopców na kursach jesienno-zimowych, a dziewczęta na kursach wiosenno-letnich, jako naczelne zadanie stawiał wychowanie Polaka-katolika - podobnie jak inne uniwersytety założone później przez Towarzystwo Czytelni Ludowych (w Zagórzu na Kaszubach - w 1926 roku i Odolanowie na południu Wielkopolski, z przeznaczeniem dla młodzieży ze Śląska - w 1927 roku). Opisując profil uniwersytetu, ks. Ludwiczak podkreślał: „idea narodowa jest nam wszystkim przewodnią, a z narodową ideą łączymy jak najścislej ideę religijną". Realizowany w nim program charakteryzował się wyraźną dominacją treści historyczno-literackich (dużo czasu przeznaczano na wykłady z języka polskiego, historii Polski i historii powszechnej, literatury), choć obecne były także - w mniejszym jednak zakresie - treści z obszaru nauk przyrodniczych czy wiadomości z gospodarstwa rolnego i domowego. W oddziaływaniach wychowawczych w uniwersytecie wykorzystywano nie tylko treści wykładów, ale także treści popołudniowych dyskusji, pogadanek, przedstawień, wycieczek ${ }^{12}$.

\section{Koncepcja „wiejskiego" uniwersytetu ludowego Ignacego Solarza}

Profil kształcenia w Dalkach był ogólny, stąd w zasadzie w placówce tej nie przygotowywano do pełnienia ról zawodowych. Ks. Ludwiczak eksponował w swoich placówkach zadania wychowawcze i społeczno-kulturalne. Wychowankowie uniwersytetu ks. Ludwiczaka powinni powracać do swoich środowisk i gospodarstw i tam animować życie społeczne w oparciu o wartości narodowe i chrześcijańskie. W rzeczywistości często pełnili później funkcje bibliotekarzy TCL, byli prezesami, sekretarzami bądź członkami zarządów Katolickich Stowarzyszeń Młodzieży, angażowali się w działalność Akcji Katolickiej ${ }^{13}$. War-

Zob. Wiejskie uniwersytety ludowe w Polsce. Biuletyn konferencji ośrwiatowej poświęconej sprawie uniwersytetów ludowych (Eowicz, 7-9 marca 1937 r.), Warszawa 1938, s. 109, 137; J. Sutyła, Miejsce ksztatcenia dorostych w systemie oświatowym II Rzeczypospolitej, dz. cyt., s. 144-146; K. Kabziński, Powstanie i dziatalność uniwersytetów ludowych, dz. cyt., s. 114-115.

13 J. Sutyła, Miejsce ksztatcenia dorostych w systemie oświatorwym II Rzeczypospolitej, dz. cyt., s. 146; M. Rosalska, Katolickie uniwersytety ludowe, dz. cyt., s. 27-28; K. Kabziński, Porwstanie i dziatalność uniwersytetów ludowych, dz. cyt., s. 112. 
to nadmienić, że ks. Ludwiczak w ramach realizowanej przez siebie koncepcji pedagogicznej podjął również udaną próbę "przedłużonego oddziaływania uniwersytetów ludowych" poprzez kontynuację aktywności byłych słuchaczy uniwersytetów ludowych w działalności - przeznaczonego specjalnie dla nich - Towarzystwa „Promień” (wydającego również dla słuchaczy i absolwentów uniwerstetów ludowych własny kwartalnik pod tą samą nazwą̨ $)^{14}$.

Profil kształcenia w uniwersytecie w Dalkach nie satysfakcjonował części młodzieży wiejskiej, radykalizującej się pod względem społecznym i ideowym, oraz związanych $z$ nią działaczy ludowych starszego pokolenia. W tych środowiakach uznawano, że jest on za mało „wiejski”. Podkreślano, że słuchacze nie uzyskiwali w tej placówce wiedzy o wsi, jej kulturze, potrzebach i dążeniach. Wprawdzie przyznawano, że jego absolwenci dobrze znali dzieje ojczyste, lecz zarazem zwracano uwagę, że nie znali dostetcznie historii własnej warstwy społecznej.

W środowiskach radykalizującej sie społecznie młodzieży wiejskiej i wśród związnych z nią ludowców podkreślano coraz bardziej nieodzowność powołania do życia własnej placówki tego rodzaju, o „rzeczywiście chłopskim" charakterze. Pomocy w realizacji tego przedsięwzięcia udzielił Związek Polskiego Nauczycielstwa Szkół Powszechnych, który wziął na siebie koszty utrzymania zakładu wychowawczego. W rezultacie 1 listopada 1924 roku uruchomiono drugi polski uniwersytet ludowy w Szycach. Rekrutacją kandydatów do niego zajęły się organizacje młodzieży wiejskiej (na początku głównie ówczesny Centralny Związek Młodzieży Wiejskiej, a pod koniec lat 20. radykalny pod względem społecznym i politycznym Związek Młodzieży Wiejskiej Rzeczypospolitej Polskiej „Wici”). Stanowisko dyrektora objął natomiast Ignacy Solarz ${ }^{15}$.

Uniwersytet ludowy w Szycach pracował pod kierownictwem Solarza do 1931 roku. W tym właśnie roku Związek Nauczycielstwa Polskiego (kontynuujący tradycje ZPNSP) podją decyzję o zawieszeniu działalności tej placówki. Krok ten Związek motywował trudnościami finansowymi ${ }^{16}$.

14 K. Kabziński, Powstanie i dziatalność uniwersytetów ludowych, dz. cyt., s. 116.

15 J. Sutyła, Miejsce kształcenia dorostych w systemie oświatowym II Rzeczypospolitej, dz. cyt., s. 147; J. Kowal, „Wici”. Powstanie i dziatalność spoteczno-wychowawcza 1928-1939, Warszawa 1964, s. 41.

16 I. Solarz, Szyce zawieszone, w: Wspomnienia o Ignacym Solarzu „Chrzestnym”, wybór i oprac. Z. Mierzwińska-Szybka, Warszawa 1983, 
Z inicjatywy Związku Młodzieży Wiejskiej Rzeczypospolitej Polskiej „Wici” (ZMW RP „Wici”) utworzono z początkiem 1932 roku wspominaną już wcześniej - Spółdzielnię Rolniczą dla Prowadzenia Uniwersytetów Wiejskich ${ }^{17}$. Oprócz działaczy młodochłopskich w ścisłym kierownictwie tej instytucji znaleźli się również przedstawiciele starszej generacji ludowców i związanych z tym środowiskiem działaczy oświatowych i uczonych: Franciszek Bujak, Jadwiga Dziubińska, Irena Kosmowska, Stanisław Kot, Maksymilian Malinowski, Leon Marchlewski, Zygmunt Nowicki, Maciej Rataj, Helena Ralińska, Stanisław Thugutt. Na bazie tej spółdzielni, przy dużej pomocy młodzieży z powiatu przeworskiego i wkładzie finansowym młodzieży zorganizowanej w ZMW RP „Wici”, otwarto nowy Wiejski Uniwersytet Orkanowy w Gaci Przeworskiej. Obowiązki kierownika ponownie powierzono Ignacemu Solarzowi.

Ignacy Solarz w kierowanych przez siebie placówkach podjął próbę realizacji koncepcji „chłopskiej szkoły”, w której - co należy podkreślić - profil edukacji wynikał przede wszystkim z powiązań z ruchem młodochłopskim oraz $z$ tendencji do wychowania młodzieży wiejskiej w ścisłej łączności z warstwą chłopską i w duchu jej dążeń do społeczno-kulturalnej przebudowy wsi i całego państwa. Solarz był w rzeczywistości głównym twórcą tej koncepcji. Dla niego właśnie naczelną ideą, która przyświecać miała działalności uniwersytetu ludowego, było wprowadzenie chłopów do czynnej i głównej roli twórczej w historii, „wychowanie w masie ludowej - jak twierdził - zdolności do urzeczywistnienia dojrzałej, wysoce etycznej demokracji”"18. Ideę tę rozwinął i uszczegółowił m.in. podczas konferencji społeczno-ideowej i programowej ZMW RP „Wici” w Kępie Celejowskiej w 1933 roku. Mówił wtedy, że należy „wieś wprowadzić na własną drogę; wstrzymać bezkrytyczny bieg i wstępowanie w ślady, a dać oddech, odnalezienie siebie, swej duszy, wywołać samopoczucie własnej wartości, godność grupową, radość we własnym tworzeniu”. Dodawał przy tym, że trzeba

s. 71. Praca w tej placówce została wznowiona po rocznej przerwie już pod innym kierownictwem.

17 Por. Odezwa Spótdzielni dla Prowadzenia Uniwersytetów Wiejskich, w: Związek Mtodzieży Wiejskiej RP „Wici” w walce o postęp i sprawiedliwośc spoteczną. Wybór dokumentów 1928-1948, oprac. E. Gołębiowski, S. Jarecka-Kimlowska, Warszawa 1978, s. 81-82. 
„rozszerzać horyzonty poza wieś i poprzez miasto dalej w świat, ale nie trzeba ze wsi robić miasta, jak z Polski - Danii czy Francji. Trzeba wieś ośmielić przez styczność z najwybitniejszymi przedstawicielami kultury z ominięciem filistrów, snobów, poganiaczy i kataryniarzy kulturalnych, trzeba też wzmocnić wieś, by do świata przemówiła sama" ${ }^{19}$.

Uniwersytet ludow Solarza był zakładem wychowawczym o charakterze ogólnokształcącym, przeznaczonym dla młodzieży wiejskiej w wieku poszkolnym. Nie chodziło w nim jednak o zaznajamianie wychowanków z podstawami usystematyzowanej wiedzy, ale przede wszystkim o kształtowanie światopoglądu, przygotowanie do uczestnictwa w społeczno-kulturalnym życiu wsi i narodu. Wychowankowie placówek kierowanych przez Solarza mieli odegrać przodującą rolę w społeczno-kulturalnej i gospodarczej aktyzwizacji wsi. Uniwersytet ludowy w wersji proponowej i realizowanej przez niego miał dostarczać - jak można to wyrazić słowami Stanisława Miłkowskiego, bliskiego Solarzowi działacza i ideologa ruchu młodochłopskiego - ,inteligencji samorodnej wyłonionej z gromady chłopskiej"20, na której opierać się powinna owa przebudowa społeczno-kulturowa wsi (przekształcanie środowiska wsi, dokonywane jego własnymi siłami).

Treści kształcenia realizowane na kilkumiesiecznych kursach nie były ustalone raz na zawsze, ich zakres nie był sztywny. Najogólniej rzecz biorąc, program kształcenia ulegał ciągłej ewolucji, uwzględniając coraz szerzej - czego brakowało w placówkach ks. Ludwiczaka treści dotyczące życia współczesnej wsi i kraju oraz ruchu ludowego. Oprócz historii i literatury, coraz więcej miejsca zajmowała problematyka realizowana w cyklu tzw. wykładów przyrodniczych, tematy wiejskie (np. kultura ludowa, dzieje chłopów i ruchu ludowego), tematy określane jako pomocnicze (np. „Polska dzisiejsza”, samorząd wiejski, spółdzielczość, teatr amatorski, zagadnienia gospodarcze wsi, kalkulacje gospodarskie).

Profil kształcenia i wychowania w uniwersytetach ludowych Ignacego Solarza ${ }^{21}$ oraz sposoby jego realizacji stanowiły jedną z najbardziej

19 I. Solarz, Gtówne czynniki ksztattujące duchowośc cztowieka wsi, „Młoda Myśl Ludowa"1933, nr 8-10, s. 41.

20 S. Miłkowski, Agraryzm jako forma przebudowy ustroju spotecznego, Kraków 1934, s. 81.

21 Na ten temat istnieje już stosunkowo bogata literatura. Zob. m.in.: Ignacy Solarz i jego uniwersytet ludowy 1924-1939, oprac. F. Popławski, S. Dyksiński, Warszawa 
wymownych egzemplifikacji tzw. kreatywnego nurtu oświaty pozaszkolnej Polski międzywojennej. W opinii jego wybitnego reprezentanta i promotora - Kazimierza Korniłowicza (ściśle też związanego z ruchem młodochłopskim lat dwudziestych ${ }^{22}$ ), ważnym zadaniem edukacji pozaszkolnej powinno być kształcenie twórczej osobowości poprzez wyzwalanie i stymulowanie zdolności tworzenia w sferze intelektualnej, artystycznej, gospodarczej i społecznej. Praca oświatowa według niego nie może poprzestawać jedynie na szerzeniu wartości kulturalnych (kierunek ekstensywny oświaty pozaszkolnej), ale winna dostarczać pomocy w ich tworzeniu, rozbudzać i wzmagać oryginalną twórczość jednostek i grup społecznych (kierunek kreatywny) ${ }^{23}$.

Rozbudzaniu i wzmaganiu tej „twórczości” służyły określone treści kształcenia i wychowania oraz związane z nimi formy i metody wykorzystywane w codziennej praktyce pedagogicznej uniwersytetów Solarza: wykład, referaty przygotowywane przez wychowanków i ich udział w dyskusjach, wycieczki, specyficzna organizacja życia społeczności uniwersyteckiej (oparta na rodzinnej atmosferze), samorząd wychowanków, teatr, włączanie się w życie społeczne najbliższego środowiska - otoczenia uniwersytetu.

W tym miejscu warto zwrócić uwagę na ową specyficzną organizację życia społeczności uniwersyteckiej. Jej zewnętrznymi przejawami, świadczącymi zarazem o charakterystycznym klimacie wychowawczym panującym w uniwersytetach w Szycach i w Gaci, były m.in.: wspólny dom, wspólne posiłki, wspólna praca i wspólne spędzanie czasu wolnego, odnoszenie się do innych jak do członków rodziny, nazywanie dyrektora „Chrzestnym”, jego żony Zofii - „Chrzestną”, pozostałych wykładowców - „Swokami”. Używanie przez słuchaczy tych ostatnich określeń („chrzestny”, „swok”) dawało im poczucie

1965; L. Turos, Patrzé́szeroko i daleko. Dziedzictwo pedagogiczne Ignacego Solarza, Warszawa 1983; W. Jamrożek, Wiejski uniwersytet ludowy Ignacego Solarza, w: Historia. Spoteczeństwo. Wychowanie. Księga pamiatkowa dedykowana Profesorowi Józefowi Miąso, red. K. Bartnicka i in., Pułtusk - Warszawa 2004.

22 Zob. M. Mioduchowska, Centralny Zwiqzek Mtodzieży Wiejskiej 1912-1928, Warszawa 1984, s. 63, 195, 299, 300, 356; Zwiqzek Mtodzieży Wiejskiej RP "Wici”w walce, dz. cyt., s. 374.

23 Zob. O. Czerniawska, Kazimierz Kornitowicz jako organizator, dziatacz i badacz oświaty dorostych, w: K. Korniłowicz, Pomoc spoteczno-kulturalna dla mtodzieży pracujacej i dorostych. Wybór pism, Wrocław 1976, s. XVII-XVIII, XXIV, XXXIII-XXXIV. 
bliskości z nauczycielami, jednocześnie wyrażało ich szacunek do wychowawców. „W nowych tytułach - jak zauważał to sam Solarz jest wiejska prostota i bezpośredniość, uznanie zwyczajnego i duchowego pokrewieństwa, a niemniej i szacunek dla sprawców duchowej przemiany - «chrztu» ${ }^{24}$.

\section{5. „Chłopska szkoła” Ignacego Solarza a inne uniwersytety ludowe}

$\mathrm{Na}$ podstawach ideowych, programowych i organizacyjnych zbliżonych do głównych założeń koncepcji wiejskiego uniwersytetu ludowego Ignacego Solarza (nawiązującego w sposób twórczy do założeń ruchu uniwersytetów ludowych zrodzonego w Danii) opierały swoją działalność inne uniwersyety związane z obozem ludowym i ruchem młodochłopskim. W pierwszej kolejności wymienić tutaj należy Uniwersytet Ludowy im. Stefana Żeromskiego w Nałęczowie (otwarty w 1930 roku) i Uniwersytet Ludowy im. Jana Kasprowicza w Nietążkowie (powołany do życia w 1937 roku). Koncepcja „chłopskiej szkoły” Solarza oddziaływała także na inne placówki oświatowe tego rodzaju, zwłaszcza uniwersytety prowadzone przez Towarzystwo „Przodownik” - Towarzystwo Wiejskich Uniwersytetów Ludowych czy też przez Liceum Krzemienieckie na Wołyniu (w Michałówce i Różynie).

Do ideowych podstaw zbliżonych do głównych założeń koncepcji Solarza odwoływała się także działalność Uniwersytetu Ludowego w Sokołówku, założonego w 1927 roku i prowadzonego przez wspominaną już Jadwigę Dziubińską ${ }^{25}$. W odróżnieniu od uniwersytetów

24 I. Solarz, Wspótżycie w uniwersytecie ludowym, „Praca Oświatowa” 1936, nr 4, s. 202.

25 Od 1927 roku przeprowadzono w Sokołówku sześć pięciomiesięcznych kursów. Ostatni kurs pod kierownictwem J. Dziubińskiej - po przerwie spowodowanej zaprzestaniem działalności przez placówkę w roku szkolnym 1931/32 - odbył się na przełomie 1934 i 1935 roku. Zob. m.in.: Wiejskie uniwersytety ludowe w Polsce. Biuletyn konferencji oświatowej poświeconej sprawie uniwersytetów ludowych (Eowicz, 7-9 marca 1937 r.), Warszawa 1938, s. 171; J. Cierniak, Uniwersytet ludowy w Sokotówku 1909-1939, w: Pamięć boru. Wspomnienia o Jadwidze Dziubińskiej i wybór jej przemówień, artykutów, listów, oprac. Z. Mazurowa, L. Wyszomirska, Warszawa 1968, s. 193-194. Placówka ta podjęła ponownie swoją działalność w 1938 roku (już po śmierci Dziubińskiej). 
Solarza, kursy w Sokołówku przeznaczone były tylko dla dziewcząt. Ważniejsza jednak różnica polegała na tym, że uniwersytet ludowy w ujęciu Dziubińskiej stanowić miał z jednej strony instytucję pogłębiającą przygotowanie zawodowe (szczególnie w zakresie praktyki agronomicznej), z drugiej - ogólnokształcącą nadbudowę wykształcenia ogólnorolniczego na poziomie niższym (do uniwersytetu przyjmowano właściwie absolwentki ludowych szkół rolniczych). Do programu kształcenia, oprócz problematyki humanistycznej, społeczno-politycznej i socjologiczno-pedagogicznej, wprowadzono również teoretyczne zagadnienia z zakresu przedmiotów zawodowych (zasady naukowej organizacji pracy i organizacji pracy w gospodarstwie domowym, rachunkowość gospodarstw wiejskich i kalkulację), a także dział zajęć praktycznych, obejmujących m.in. czynności zawodowe gospodyni wiejskiej. W ocenie jednego z biografów Dziubińskiej, Stanisława Michalskiego, „,zeroki profil edukacji ekonomiczno-społecznej i pedagogicznej miał m.in. ukazać humanistyczne aspekty pracy w rolnictwie"26.

Ruch uniwersyteów ludowych w Polsce międzywojennej był istotnym ogniwem szeroko rozumianej oświaty pozaszkolnej. Szczególną rolę w jego rozwoju odegrały takie postacie, jak ks. Antoni Ludwiczak, Ignacy Solarz czy Jadwiga Dziubińska (promująca wówczas nieco inny model uniwersytetu w porównaniu do koncepcji realizowanych przez te dwie pierwsze osoby). Bez wątpienia szczególne miejsce w tym ruchu zajmował Ignacy Solarz ze swoją koncepcją uniwersytetu ludowego. Tak postrzegały jego rolę również polskie władze państwowe w latach 30. XX wieku, wobec których Solarz był jednak w wyraźnej opozycji. Świadczy o tym m.in. treść listów kierowanych do Solarza przez Jędrzeja Cierniaka, pełniącego od końca lat 20. funkcję ministerialnego wizytatora oświaty pozaszkolnej (w zakresie której mieściła sie także opieka nad uniwersytetami ludowymi). W liście z 5 września 1938 roku pisał do Solarza:

„Liceum Krzemienieckie organizuje na zlecenie MWiROP [Ministerstwa Wyznań Religijnych i Oświecenia Publicznego - przyp. W.J.] konferencję w sprawach uniwersyetu ludowego w dn. 3-5 października w Krzemieńcu. 
Przewidują tam i wasz referat na temat istoty oddziaływania wychowawczego, ściślej «z doświadczeń wychowawczych»... Bardzo Was proszę - nie odmawiać - jest to, jak już Wam pisałem na wakacjach, sprawa ważna, byście mieli wpływ moralny na te instytucje i ich ducha. Proszę Was bardzo, weźcie udział w tej rzeczy, bo jednak sami wiecie, że macie wpływ na inne uniwersytety znacznie większy niż komuś tam się wydaje ${ }^{27}$.

\section{BIBLIOGRAFIA}

Bron-Wojciechowska A., Grundtvig, Wiedza Powszechna, Warszawa 1986. Cierniak J., Uniwersytet ludowy w Sokotówku 1909-1939, w: Pamięć boru. Wspomnienia o Jadwidze Dziubińskiej i wybór jej przemówień, artykutów, listów, oprac. Z. Mazurowa, L. Wyszomirska, Ludowa Spółdzielnia Wydawnicza, Warszawa 1968.

Czerniawska O., Kazimierz Kornitowicz jako organizator, dziatacz i badacz oświaty dorostych, w: K. Korniłowicz, Pomoc spoteczno-kulturalna dla mtodzieży pracujacej i dorostych. Wybór pism, Zakład Narodowy im. Ossolińskich, Wrocław 1976.

Fołta W., Kontakty Jędrzeja Cierniaka z Wiejskim Uniwersytetem Orkanowym w Gaci, w: Wspomnienia o Jędrzeju Cierniaku, wybór i oprac. Z. Mazurowa, L. Wyszomirska, Ludowa Spółdzielnia Wydawnicza, Warszawa 1982.

Ignacy Solarz i jego uniwersytet ludowy 1924-1939, oprac. F. Popławski, S. Dyksiński, Ludowa Spółdzielnia Wydawnicza, Warszawa 1965.

Jamrożek W., Kongresy i zjazdy pedagogiczne w rozwoju polskiej myśli i praktyki edukacyjnej (do 1939 roku), Wydawnictwo Naukowe UAM, Poznań 2015.

Jamrożek W., Wiejski uniwersytet ludowy Ignacego Solarza, w: Historia. Spoteczeństwo. Wychowanie. Ksiega pamiątkowa dedykowana Profesorowi Józefowi Miaso, red. K. Bartnicka i in., Wyższa Szkoła Humanistyczna PAN, Pułtusk - Warszawa 2004.

Kabziński K., Funkcja spoteczno-wychowawcza i oswiatowa Towarzystwa Czytelni Ludowych (1880-1939), Zakład Narodowy im. Ossolińskich, Wrocław 1985.

27 Cyt. za W. Fołta, Kontakty Jędrzeja Cierniaka z Wiejskim Uniwersytetem Orkanowym w Gaci, w: Wspomnienia o Jędrzeju Cierniaku, wybór i oprac. Z. Mazurowa, L. Wyszomirska, Warszawa 1982, s. 125. Solarz nie wziął bezpośredniego udziału w konferencji w Krzemieńcu. Placówkę oświatową w Gaci Przeworskiej reprezentowała wówczas jego żona - Zofia. Por. Z. Solarzowa, Z doświadczeń w wiejskim uniwersytecie ludowym, w: Wiejskie uniwersytety ludowe w Polsce. Biuletyn konferencji oświatorvej poświęconej sprawie uniwersytetów ludowych (Krzemieniec, 6-8 października 1938), Warszawa 1939 , s. 25-35. 
Kabziński K., Powstanie i dziatalność uni wersytetów ludowych Towarzystwa Czytelni Ludowych w okresie międzywojennym, w: Instytucjonalne formy edukacji dorostych w Drugiej Rzeczypospolitej, red. E. Sapia-Drewniak, A. Stopińska-Pająk, Akademickie Towarzystwo Andragogiczne, Warszawa 2001.

Kowal J., „Wici”. Powstanie i dziatalność spoteczno-wychowawcza 1928-1939, Ludowa Spółdzielnia Wydawnicza, Warszawa 1964.

Maliszewski T., Uniwersytety ludowe na ziemiach polskich w XX stuleciu, w: Uniwersytet ludowy - szkota dla życia, red. M. Byczkowski, T. Maliszewski, E. Przybylska, Kaszubski Uniwersytet Ludowy im. J. Wybickiego, Wieżyca 2003.

Michalski S., Wiedza rolnicza w walce o postęp na wsi. Rzecz o Jadwidze Dziubinskiej, PWN, Warszawa - Poznań 1981.

Miłkowski S., Agraryzm jako forma przebudowy ustroju spotecznego, Związek Młodzieży Wiejskiej Spółdzielni Oświatowej, Kraków 1934.

Mioduchowska M., Centralny Zwiqzek Mtodzieży Wiejskiej 1912-1928, Ludowa Spółdzielnia Wydawnicza, Warszawa 1984.

Odezwa Spótdzielni dla Prowadzenia Uniwersytetów Wiejskich, w: Zwiq̨zek Mtodzieży Wiejskiej RP „Wici” w walce o postęp i sprawiedliwość spotecznq. Wybór dokumentów 1928-1948, oprac. E. Gołębiowski, S. Jarecka-Kimlowska, Ludowa Spółdzielnia Wydawnicza, Warszawa 1978.

Pilch T., Uniwersytet ludowy, w: Encyklopedia pedagogiczna XXI wieku, t. 6, Wydawnictwo Akademickie „Żak”, Warszawa 2007.

Popławski F., Polski uniwersytet ludowy, Wydawnictwo Spółdzielcze, Warszawa 1985.

Radlińska H., Oświata i kultura wsi polskiej. Wybór pism, oprac. H. Brodowska, L. Wojtczak, Ludowa Spółdzielnia Wydawnicza, Warszawa 1979.

Rosalska M., Katolickie uniwersytety ludowe wobec przemian wspótczesnej wsi polskiej, Garmond, Poznań 2004.

Solarz I., Gtówne czynniki ksztattujące duchowość cztowieka wsi, „Młoda Myśl Ludowa” 1933, nr 8-10.

Solarz I., Szyce zawieszone, w: Wspomnienia o Ignacym Solarzu „Chrzestnym”, wybór i oprac. Z. Mierzwińska-Szybka, Ludowa Spółdzielnia Wydawnicza, Warszawa 1983.

Solarz I., Wiejski Uniwersytet Orkanowy. Cel i program, Instytut Oświaty Dorosłych, Warszawa 1937.

Solarz I., Wspótżycie w uniwersytecie ludowym, „Praca Oświatowa” 1936, nr 4.

Solarzowa Z., Z doświadczeń w wiejskim uniwersytecie ludowym, w: Wiejskie uniwersytety ludowe w Polsce. Biuletyn konferencji oświatowej poświęconej sprawie uniwersytetów ludowych (Krzemieniec, 6-8 października 1938), red. J. Cierniak, Z. Mierzywińska, W. Radwan, Spółdzielnia Wydawnicza „Pomoc Oświatowa”, Warszawa 1939.

Sutyła J., Miejsce ksztatcenia dorostych w systemie oświatowym II Rzeczypospolitej, Zakład Narodowy im. Ossolińskich, Wrocław 1982. 
Turos L., Patrzeć szeroko i daleko. Dziedzictwo pedagogiczne Ignacego Solarza, Wydawnictwo Spółdzielcze, Warszawa 1983.

Turos L., Uniwersytet ludowy Ignacego Solarza i jego wychowankowie, Ludowa Spółdzielnia Wydawnicza, Warszawa 1970.

Wiejskie uniwersytety ludowe w Polsce. Biuletyn konferencji oświatowej poświęconej sprawie uniwersytetów ludowych (Eowicz, 7-9 marca 1937 r.), red. Z. Mierzwińska-Szybka, W. Radwan, „Książnica dla Rolników”, Warszawa 1938.

Wojciechowski K., Poczq̨tki i rozwój uniwersytetów ludowych w Polsce do 1945 roku, w: Uniwersytety ludowe w Polsce i za granica, red. A. Bron-Wojciechowska, Ludowa Spółdzielnia Wydawnicza, Warszawa 1977.

\section{ADRES DO KORESPONDENCJ}

Dr hab. Wiesław Jamrożek, prof. UAM

Uniwersytet im. Adama Mickiewicza w Poznaniu

Wydział Studiów Edukacyinych, Zakład Historii Wychowania

jawies@o2.pl 